\title{
Pengaruh Ukuran Adsorben Kulit Pisang Kepok terhadap Penurunan Nilai Asam Lemak Bebas Minyak Goreng Bekas
}

\author{
Joko Suryadi ${ }^{1}{ }^{*}$, Endang Widiastuti ${ }^{1}$, Mohammad Idris Asyraf Ali ${ }^{1}$, Zulfany Ali ${ }^{1}$ \\ ${ }^{1}$ Jurusan Teknik Kimia, Politeknik Negeri Bandung \\ Jln. Gegerkalong Hilir, Ds. Ciwaruga, Bandung 40012 \\ EE-mail: joko.suryadi@ polban.ac.id
}

\begin{abstract}
ABSTRAK
Penelitian ini bertujuan untuk mengukur tingkat perbaikan kualitas terhadap jelantah yang dapat dilakukan kulit pisang kepok. Minyak jelantah yang digunakan dalam penelitian ini diperoleh dari penjual gorengan dan didiamkan selama 24 jam sebelum diproses lebih lanjut. Metode adsorpsi yang akan dilakukan dalam penelitian ini adalah metode batch pada temperature $40{ }^{\circ} \mathrm{C}$ dengan waktu kontak pada 30 dan 60 menit. Kecepatan pengadukan diatur pada $500 \mathrm{rpm}$. Ukuran adsorben divariasikan pada 35, 60, dan 230 mesh. Karakterisasi yang dilakukan pada adsorben adalah kapasitas adsorpsi dengan variasi massa menggunakan metode iodin. Parameter kualitas jelantah adalah persen perubahan nilai asam lemak bebas sebelum dan sesudah perlakuan adsorpsi. Karakteristik kulit pisang sebagai adsorben dengan efisiensi terbesar ditunjukkan pada kulit pisang pada ukuran 230 mesh sebanyak 2 gram sebesar 73,38\%. Persentase penurunan asam lemak bebas terbesar ditunjukkan pada kulit pisang pada ukuran 35 mesh dengan pengadukan selama 60 menit dengan nilai 8,57\%.
\end{abstract}

Kata kunci: Adsorben, asam lemak bebas, minyak jelantah, pisang kepok

\begin{abstract}
The aim of this research is measuring the recovery of cooking oil quality that performed by kepok banana's peel. The cooking oil used in this research was obtain from snack seller and deposited for 24 hours before further processed. Batch adsorption method was used in this research on $40{ }^{\circ} \mathrm{C}$ with 30 and 60 minutes on contact time. Speed of agitation was set on $500 \mathrm{rpm}$. The adsorption size was at 35, 60, and 230 mesh. The adsorbent characterization at several mass was determined by iodine number method that expressed as adsorbent capacity. Quality parameter of used cooking oil was determined by shifting value of free fatty acid before and after adsorption process. The greatest efficiency of adsorbent capacity value was $73.38 \%$ showed by 230 mesh of banana peel at 2 grams. The greatest percentage of free fatty acid value depletion was $8.57 \%$ showed by 35 mesh banana peel in 60 minutes of agitation.
\end{abstract}

Keywords: Adsorbent, free fatty acids, waste cooking oil, kepok banana

\section{PENDAHULUAN}

Konsumsi minyak goreng sawit dalam rumah tangga di Indonesia dari tahun 2003 yang besarnya 5,475 L/kapita/tahun secara signifikan meningkat menjadi 11,680 L/kapita/tahun pada tahun 2016 dan diprediksi akan meningkat pada tahuntahun berikutnya (Kementerian Pertanian, 2017). Peningkatan angka konsumsi minyak goreng sawit tersebut menyebabkan limbah minyak goreng bekas juga meningkat. Limbah minyak goreng bekas yang dihasilkan tersebut apabila tidak ditanganai dengan benar maka akan menyebabkan pencemaran lingkungan. Selain itu, pemakaian minyak goreng bekas yang berkali kali akan menyebabkan timbulnya masalah kesehatan. Penggunaan 
minyak goreng sawit berkali kali ini dapat dijumpai pada sebagian besar pelaku usaha penjual gorengan di masyarakat (Suryandari, 2014).

Buah pisang merupakan makanan yang lazim dalam konsumsi masyarakat luas di Indonesia baik dimakan langsung ataupun diolah menjadi produk makanan lebih lanjut. Salah satu jenis buah pisang yang umum dikonsumsi adalah jenis pisang kepok. Tanaman pisang kepok dapat tumbuh baik di daerah beriklim tropis dan membutuhkan cayaha matahari hingga ketinggian 2000 meter di atas permukaan laut. Pisang kepok banyak diolah menjadi tepung pisang, keripik, pisang goreng, dan sebagainya (Zulkifli dkk., 2018).

Pemanfatan buah pisang dalam industri makanan menghasilkan limbah utama berupa kulit pisang. Pemanfaatan kembali kulit pisang secara umum di masyarakat luas masih terbatas pada makanan hewan ternak. Sebagian besar kulit pisang dibuang dan tidak dimanfaatkan lebih lanjut. Adanya dua macam bahan sisa dalam satu macam industri makanan terutama usaha gorengan ini melatarbelakangi solusi dalam pemanfaatan limbah kulit pisang sekaligus perbaikan kualitas minyak goreng bekas pakai. Limbah kulit pisang khususnya pisang kepok diharapkan mampu berperan sebagai adsorben terhadap minyak goreng bekas pakai sehingga kualitasnya menjadi naik. Selain warna, kualitas dari minyak goreng pada umumnya ditentukan dari besarnya nilai asam lemak bebas (Yilmas \& Bulut, 2012; Kusumawardhani, 2018) dan angka peroksida (Wannahari \& Nordin, 2012).

Metode adsorpsi dengan kulit pisang digunakan dalam penelitian ini karena relatif lebih murah jika dibandingkan dengan metode fotokatalis dan lebih praktis dibandingkan dengan menggunakan adsorben dari bahan-bahan biomassa yang diubah menjadi arang aktif. Penelitian mengenai kulit pisang yang tanpa diaktifkan dahulu menjadi arang aktif telah dilakukan sebagai adsorben zat warna metilen blue karena adanya gugus karboksil dalam asam galakturonik disamping senyawa-senyawa lain yang terdapat di dalamnya.

Pada penelitian ini kulit pisang dihipotesiskan dapat berperan sebagai adsorben untuk asam lemak bebas disamping sebagai adsorben untuk zat warna metilen blue (Fitriani dkk., 2015). Produk minyak goreng hasil adsorpsi lebih mempunyai nilai guna di bidang non pangan bila dimanfaatkan secara lebih lanjut. Perbaikan minyak goreng bekas yang dilihat dari parameter penurunan asam lemak bebas dapat menjadikan minyak tersebut dimanfaatkan lebih lanjut untuk diolah menjadi bahan baku biodiesel (Ismaila dkk., 2017).

\section{METODE PENELITIAN}

\section{Bahan-bahan}

Bahan-bahan yang digunakan dalam penelitian ini adalah kulit pisang kepok, minyak goreng bekas, aquades, $\mathrm{NaOH}$ (analytical grade), asam oksalat (analytical grade), indikator pp, etanol (analytical grade), iodin (analytical grade), natrium tiosulfat (analytical grade), kanji (teknis), dan $\mathrm{HCl}$ (analytical grade).

\section{Prosedur Kerja}

Prosedur kerja dalam penelitan ini meliputi tiga bagian antara lain sebagai berikut:

\section{Pembuatan Adsorben dari Kulit Pisang Kepok}

Kulit pisang dikeringkan di bawah sinar matahari langsung selama 2 hari kemudian 
dihancurkan menggunakan blender elektrik. Kulit pisang yang telah dihaluskan diayak dengan variasi ukuran 35, 60, dan 230 mesh. Ketiga kulit pisang dengan ukuran partikel yang berbeda beda kemudian masing-masing disimpan di tempat yang kedap udara. Pemilihan ukuran adsorben tersebut dipilih berdasarkan analogi penelitian sebelumnya yang telah dilakukan dengan menggunakan bagasse dengan ukuran di atas 35 mesh (Wannahari \& Nordin, 2012). Oleh karena itu pada penelitian ini dibuat rentang mulai dari 35 mesh hingga tiga variabel secara bebas.

\section{Adsorpsi Minyak Goreng Bekas dengan Metode Batch}

Minyak goreng bekas sebanyak $50 \mathrm{~g}$ dipanaskan hingga mencapai temperatur konstan $40{ }^{\circ} \mathrm{C}$. Adsorben kulit pisang ditambahkan sebanyak 1 gram. Pengadukan dilakukan dengan kecepatan $500 \mathrm{rpm}$. Variasi waktu kontak adsorpsi dilakukan pada 30 dan 60 menit. Minyak jelantah hasil proses adsorpsi disaring untuk kemudian ditentukan nilai asam lemak bebas. Prosedur tersebut dilakukan pada ketiga jenis ukuran adsorben.

\section{Karakterisasi Adsorben}

Karakterisasi adsorben berupa kapasitas adsorpsi dilakukan dengan cara kulit pisang pada variasi ukuran diperlakukan dengan larutan iodin yang sudah dibakukan dengan volume $20 \mathrm{~mL}$, setelah dibakukan pengocokan selama 30 detik lalu disaring. Filtrat hasil penyaringan kemudian dititrasi dengan larutan natrium tiosulfat yang sudah dibakukan juga.

\section{HASIL DAN PEMBAHASAN \\ Distribusi Ukuran Kulit Pisang}

\begin{abstract}
Distribusi kulit pisang berdasarkan ukuran pori pada proses pengayakan setelah pengeringan ditampilkan dalam Tabel 1. Nilai distribusi ukuran kulit pisang kering ditentukan dari massa yang didapatkan setelah melewati saringan dengan ukuran yang ditentukan (undersize). Distribusi ukuran kulit pisang menunjukkan ukuran yang paling banyak didapatkan dengan menggunakan metode penghalusan dengan alat penghalus konvensional.
\end{abstract}

Tabel 1. Distribusi Massa Kulit Pisang Berdasarkan Ukuran Ayakan

\begin{tabular}{ccc}
\hline No. & $\begin{array}{c}\text { Ukuran ayakan } \\
(\text { mesh })\end{array}$ & $\begin{array}{c}\text { Distribusi massa } \\
(\%)\end{array}$ \\
\hline 1. & 35 & 42,70 \\
2. & 60 & 35,44 \\
3. & 230 & 21,86 \\
\hline
\end{tabular}

Kenampakan fisik dari kulit pisang dengan ukuran 35 dan 60 mesh menunjukkan bahwa didapatkan material berupa granula dan serat-serat halus yang juga terikut dalam proses penyaringan. Sedangkan pada ukuran 230 mesh didapatkan kulit pisang dalam bentuk bubuk halus. Pada ukuran pori paling besar yaitu pada 35 mesh, merupakan distribusi massa paling besar dari kulit pisang menunjukkan bahwa proses penghalusan yang dilakukan secara mekanik dengan blender secara efektif mampu mencapai ukuran tersebut. 


\section{Karakteristik Adsorbsi dari Kulit Pisang}

Karakteristik adsorpsi dari kulit pisang dalam penelitian ini dianalogikan dengan adsorpsi yang terjadi pada karbon aktif. Hal tersebut didasarkan pada komposisi utama penyusun adsorben yang terdiri dari karbon. Pengamatan karakteristik adsorpsi dilakukan dengan metode iodin yang mengadopsi dari metode ASTM 4607. Pengamatan karakteristik adsorpsi dilakukan pada ketiga adsorben dengan ukuran berbeda-beda dengan variasi massa yang berbeda yaitu 1, 2, dan 3 gram. Hasil pengamatan karakteristik adsorbsi dengan metode iodin ditunjukkan pada Gambar 1.

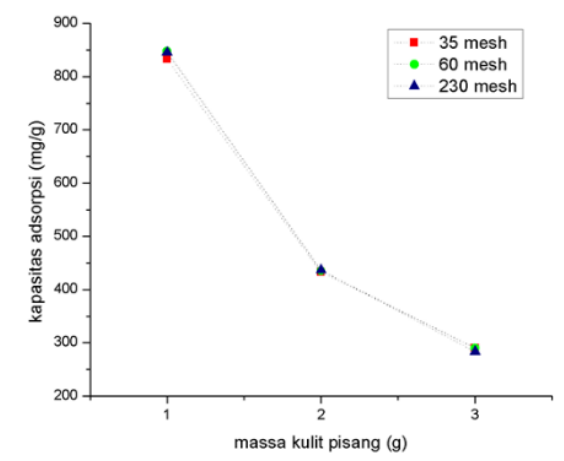

Gambar 1. Grafik Hubungan Kapasitas Adsorpsi dengan Massa Kulit Pisang

Kapasitas adsorbsi pada semua ukuran kulit pisang menunjukkan kecenderungan penurunan yang berbanding lurus dengan massa kulit pisang. Hal ini disebabkan adanya kejenuhan dari kulit pisang sebagai adsorben pada kondisi batas nilai massa sehingga dengan penambahan massa adsorben tidak terlalu meningkatkan kemampuan kulit pisang dalam mengadsorpsi bahan adsorbat.

Kapasitas adsorben dengan metode iodin menunjukkan bahwa luas permukaan adsorben tidak secara signifikan memberikan pengaruh pada kondisi massa adsorben yang sama. Hal ini ditunjukkan pada gambar 1 dimana ukuran mesh pada massa yang sama tidak menunjukkan perubahan signifikan. Hal ini disebabkan proses adsorpsi dari kulit pisang kepok merupakan jenis adsorpsi kimia yaitu bergantung pada gugus aktif yang mampu mengadsorpsi suatu adsorbat.

Selain kapasitas adsorpsi, karakterisasi dari adsorben dinayatakan dengan besaran efektifitas sebagai adsorben. Efektifitas adsorben yang dinyatakan dengan persen didapatkan dari nilai perbandingan antara konsentrasi adsorbat yang terserap dibandingkan dengan nilai konsentrasi adsorbat awal. Hasil pengamatan efektifitas adsorben kulit pisang disajikan dalam grafik pada Gambar 2. yang menyatakan hubungan antara efisiensi adsorbsi dengan massa kulit pisang pada berbagai ukuran kulit pisang.

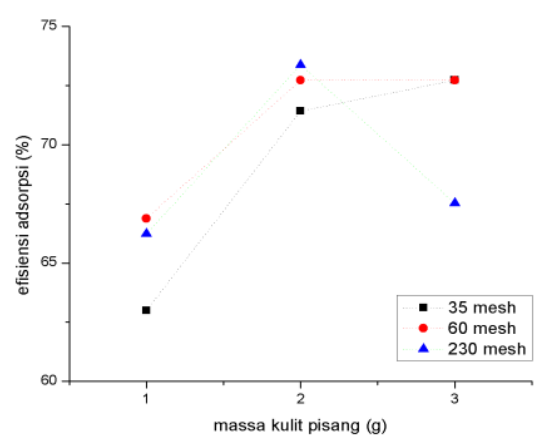

Gambar 2. Grafik Hubungan Kapasitas Adsorpsi dengan Massa Kulit Pisang

Efisiensi adsorpsi secara umum mengalami kenaikan seiring dengan kenaikan massa hingga 2 gram. Hal ini disebabkan adanya massa adsorben yang bertambah sehingga menyediakan media adsorpsi yang lebih banyak. Untuk massa adsorben lebih dari 2 gram, pada ukuran 230 mesh mengalami penurunan yang drastis selain karena kejenuhan dari adsorben juga diakibatkan oleh kerusakan 
struktur fisik dari adsorben yang disebabkan karena panas. Hal ini tidak terjadi pada adsorben dengan ukuran yang lebih kasar (35 dan 60 mesh) yang cenderung lebih tahan terhadap panas dikarenakan ukurannya. Hal tersebut diperkuat dengan adsorben pada ukuran 35 mesh yang efisiensinya berbanding lurus dengan massa dari adsorben kulit pisang. Untuk adsorben dengan ukuran 60 mesh, memiliki efisiensi yang lebih tinggi pada kondisi massa $2 \mathrm{~g}$ namun efektifitasnya cenderung konstan setelah massanya ditambahkan. Kejenuhan yang ditunjukkan oleh adsorben 60 mesh pada massa yang lebih tinggi disebabkan akumulasi dari adsorben yang mengalami kerusakan menghambat daya adsorptivitasnya.

\section{Analisis Mutu Minyak Goreng Bekas berdasarkan Nilai Asam Lemak Bebas}

Salah satu parameter mutu dari minyak goreng adalah nilai asam lemak bebas. Semakin tinggi nilai asam lemak bebas, maka kualitas dari minyak goreng akan menurun. Dalam penelitian ini, kulit pisang diamati kemampuannya dalam menurunkan nilai asam lemak bebas dari minyak goreng jelantah. Nilai asam lemak bebas dari minyak jelantah dan minyak hasil adsorpsi dinyatakan dalam Tabel 2.

Tabel 2. Nilai Asam Lemak Bebas Minyak Jelantah dan Minyak Jelantah Setelah Adsorbsi

\begin{tabular}{|c|c|c|c|}
\hline \multirow{3}{*}{$\begin{array}{l}\text { Ukuran } \\
\text { (mesh) }\end{array}$} & \multicolumn{3}{|c|}{ Kandungan Asam lemak bebas (\%) } \\
\hline & Minyak jelantah & $\begin{array}{l}\text { Minya } \\
\text { setela }\end{array}$ & $\begin{array}{l}\text { lantah } \\
\text { lsorbs }\end{array}$ \\
\hline & \multirow{4}{*}{1,29} & $\begin{array}{c}30 \\
\text { menit }\end{array}$ & $\begin{array}{c}60 \\
\text { menit }\end{array}$ \\
\hline 35 & & 1,27 & 1,18 \\
\hline 60 & & 1,28 & 1,20 \\
\hline 230 & & 1,27 & 1,23 \\
\hline
\end{tabular}

Kemampuan adsorpsi kulit pisang terhadap asam lemak bebas pada minyak goreng dilihat dari nilai efisiensi penurunannya. Hubungan antara efisiensi dari penurunan asam lemak bebas dan ukuran adsorben dinyatakan pada Gambar 3.

Secara umum waktu proses batch berpengaruh terhadap penurunan nilai asam lemak bebas pada minyak jelantah. Waktu kontak yang lebih lama menyebabkan proses adsorpsi lebih baik. Penurunan nilai asam lemak bebas paling besar yaitu $8,57 \%$ dicapai pada adsorben kulit pisang 35 mesh selama 60 menit. Selain karena waktu kontak, morfologi dari granula kulit pisang menyediakan gugus aktif lebih banyak untuk adsorbat. Pada serbuk kulit pisang (230 mesh) selama satu jam efisiensi turun dikarenakan kejenuhan dari adsorben dan pengaruh panas dalam jangka waktu yang lama menyebabkan kerusakan dari adsorben kulit pisang.

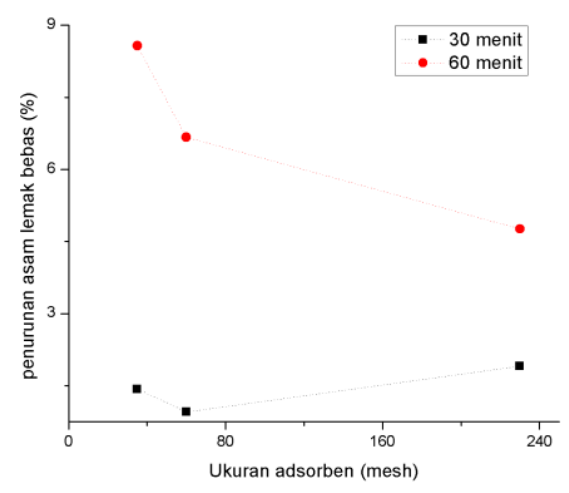

Gambar 3. Penurunan Nilai Asam Lemak
Bebas pada Variasi Ukuran Adsorben dan
Waktu

Karakter kapasitas adsorpsi dari adsorben kulit pisang jika dikaitkan denga kemampuan adsorpsi untuk minyak goreng bekas adalah kemampuannya tergantung terhadap waktu kontak pada saat proses adsorpsi. Kemampuan adsorbsi karena 
pengaruh ukuran adsorben secara pengamatan grafik juga lebih terlihat pada waktu kontak yang lebih lama.

Sisi yang berperan aktif sebagai adsorben dalam kulit pisang adalah adanya pori-pori yang merupakan sisi aktif dalam proses adsorpsi. Hal ini merupakan asumsi yang mengacu pada penelitian sebelumnya dimana pori-pori sebagai sisi aktif untuk adsorpsi (Putranti dkk., 2017). Namun dalam penelitian ini tidak dibahas mengenai pengaruh pori dalam adsorpsi pada adsorben kulit pisang. Sisi aktif dalam penelitian ini adalah lebih ke pendekatan ikatan yang terjadi. Ikatan tersebut dapat berupa atom $\mathrm{H}$ dari sisi hidrofil gugus karbohidrat kompleks pada kulit pisang. Asam lemak bebas yang mempunyai gugus polar yaitu gugus karboksil (-COOH) akan cenderung berikatan dengan sisi hidrofil dari kulit pisang dengan mekanisme ikatan hidrogen. Sifat ikatan hidrogen yang lebih lemah dibandingkan ikatan kimia baik ion maupun kovalen menyebabkan efisiensi penurunan asam lemak bebas yang lebih kecil dibandingkan dengan penelitian sebelumnya (Putranti dkk., 2017). Hal tersebut yang menyebabkan penurunan kandungan asam lemak bebas dari minyak jelantah tidak signifikan baik pada waktu kontak 30 maupun 60 menit pada semua ukuran adsorben kulit pisang.

Dari hasil tersebut dapat dikatakan bahwa kulit pisang kepok kurang dapat dimanfaatkan secara langsung menjadi adsorben untuk asam lemak bebas. Oleh karena itu perlu adanya kajian lebih lanjut mengenai proses pengolahan sebelum kulit pisang kepok tersebut agar efektif menjadi adsorben untuk asam lemak bebas. Selain itu juga perlu dilakukan kajian lebih lanjut mengenai pengaruh pori sebagai sisi aktif terhadap kemampuan kulit pisang kepok sebagai adsorben untuk asam lemak bebas pada minyak goreng bekas.

\section{SIMPULAN}

Biomassa kulit pisang memiliki efektivitas sebagai adsorben pada waktu proses 60 menit untuk menurunkan nilai asam lemak bebas terbaik pada minyak jelantah pada ukuran 35 mesh sebesar 8,57 $\%$.

\section{UCAPAN TERIMA KASIH}

Penulis mengucapkan terima kasih kepada UPPM Politeknik Negeri Polban sebagai sumber pendanaan penelitian melalui skema Penelitian Mandiri batch III.

\section{DAFTAR RUJUKAN}

Fitriani, D.; Oktiarni, D.; \& Lusiana, 2015. Pemanfaatan Kulit Pisang Sebagai Adsorben Zat Warna Methylene Blue, Jurnal Gradien, XI (2): 1091-1095

Ismaila, A.; Saiman, N.N.; Jusoh, M.; \& Zakaria, Z.Y., 2017. Adsorption of Free Fatty Acid in Biodiesel from Palm Fatty Acid Distillate using KOHActivated Starch, Chemical Engineering Transactions, LVI (1): 619-624.

Kementerian Pertanian, 2017. Buletin Konsumsi Pangan, Konsumsi Pangan, VIII (2): 53.

Kusumawardhani, $\quad$ D.A. 2018. Pemanfaatan Limbah Nasi Aking Sebagai Adsorben untuk Menurunkan Kadar Asam Lemak Bebas pada Minyak Jelantah. Skripsi tidak diterbitkan. Surabaya: Institut Teknologi Sepuluh Nopember, Jurusan Kimia.

Putranti, M.L.TA.; Wirawan, S.K.; \& Bendiyasa, I.M., 2017. Adsorption of Free Fatty Acid (FFA) in Low Grade 
Cooking Oil used Activated Natural Zeolite as Adsorbent, IOP Conference Series: Materials Science and Engineering, CCXCIX (012085): 1-8. Suryandari, E.T.; 2014. Pelatihan Pemurnian Minyak Jelantah dengan Kulit Pisang Kepok (Musa paradisiacal, Linn) untuk Pedagang Makanan di Pujasera Ngaliyan. Dimas, XIV (1): 57-70.

Wannahari, R.; \& Nordin, M.F.N., 2012. Reduction of Peroxide Value in Used Palm Cooking Oil using Bagasse Adsorbent, American International
Journal of Contemporary Research, II (1): 185-191.

Yilmaz, E.; \& Bulut, E., 2012. Frying Oil Refreshing Capacity of a New Adsorbent Mixture, Academic Food Journal, X (1): 24-29

Zulkifli, Z.; Rihayat, T.; Suryani, S.; Fachranizah, F.; Habibah, U.; Ardina, N.; Fauzi, T.; Nurhanifa, N.; Zaimahwati, Z.; \& Rosalina, R., 2018. Purification Process of Jelantah Oil using Active Charcoal Kepok's Banana. AIP Conference Proceedings, MMXIX (020022): 1-6. 